San Jose State University

SJSU ScholarWorks

Master's Theses

Master's Theses and Graduate Research

Fall 2015

\title{
The Relationship Between Organizational Justice and Various Dimensions of Pay Satisfaction
}

Xinyi Li

San Jose State University

Follow this and additional works at: https://scholarworks.sjsu.edu/etd_theses

\section{Recommended Citation}

$\mathrm{Li}$, Xinyi, "The Relationship Between Organizational Justice and Various Dimensions of Pay Satisfaction" (2015). Master's Theses. 4648.

DOI: https://doi.org/10.31979/etd.w9ac-5yj7

https://scholarworks.sjsu.edu/etd_theses/4648

This Thesis is brought to you for free and open access by the Master's Theses and Graduate Research at SJSU ScholarWorks. It has been accepted for inclusion in Master's Theses by an authorized administrator of SJSU ScholarWorks. For more information, please contact scholarworks@sjsu.edu. 


\title{
THE RELATIONSHIP BETWEEN ORGANIZATIONAL JUSTICE AND VARIOUS DIMENSIONS OF PAY SATISFACTION
}

\author{
A Thesis \\ Presented to \\ The Faculty of the Department of Psychology \\ San José State University
}

\author{
In Partial Fulfillment \\ of the Requirements for the Degree \\ Master of Science
}

by

Xinyi Li

December 2015 
(C) 2015

Xinyi Li

\section{ALL RIGHTS RESERVED}


The Designated Thesis Committee Approves the Thesis Titled

THE RELATIONSHIP BETWEEN ORGANIZATIONAL JUSTICE AND VARIOUS DIMENSIONS OF PAY SATISFACTION

by

Xinyi Li

APPROVED FOR THE DEPARTMENT OF PSYCHOLOGY

SAN JOSÉ STATE UNIVERSITY

December 2015

Dr. Megumi Hosoda Department of Psychology

Dr. Meghna Virick School of Management

Timothy Brown Radford Corporation 


\section{ABSTRACT \\ THE RELATIONSHIP BETWEEN ORGANIZATIONAL JUSTICE AND VARIOUS DIMENSIONS OF PAY SATISFACTION \\ by Xinyi Li}

Pay satisfaction has been linked to important organizational outcomes such as work performance and turnover intentions. One way to predict employees' pay satisfaction is through organizational justice. The purpose of this study was to examine the role of organizational justice perceptions in predicting various pay satisfaction dimensions. A sample of 107 employees participated in an online survey. Consistent with the hypotheses, results showed that pay-related distributive justice perceptions were a stronger predictor of pay level satisfaction than pay-related procedural justice perceptions, and that benefits-related procedural justice perceptions were a stronger predictor of benefits determination satisfaction and benefits administration satisfaction than benefits-related distributive justice perceptions. Additionally, results showed that pay-related distributive justice perceptions and procedural justice perceptions significantly and equally predicted pay structure satisfaction, pay raises satisfaction, and variable pay procedure satisfaction, and that benefits-related distributive justice perceptions and procedural justice perceptions significantly and equally predicted benefits level satisfaction. These findings suggest that organizations should make fairness a priority when distributing compensation outcomes and making compensation decisions to maintain a high level of pay satisfaction. 


\section{ACKNOWLEDGMENTS}

It goes without saying that my thesis would not have been successfully completed without the assistance and kindness of those closest to me.

First and foremost, I would like to express my sincere gratitude to my thesis committee for their diligent review and continuous support of my study and research. Dr. Megumi Hosoda is truly an inspiring thesis chair. She has provided insightful suggestions on the research and offered her encouragement throughout the development of this thesis. I am very grateful for the long discussions she had with me to figure out the details of my thesis. Dr. Meghna Virick has always been there to listen and give advice. There's no doubt that her wide knowledge and expertise in human resources were vital to my success. Mr. Tim Brown has provided insightful comments and encouragement from the perspective of a practitioner. Without his sincere help, it would not have been possible to finish this research study.

Second, a very special thanks goes out to my parents. Their patience, encouragement, and strong support enabled me to finish my thesis study. I have the deepest gratitude for their love and many years of support.

Last but certainly not least, thanks to my best friend Norm for believing in me. I appreciate his sincere assistance. Studying in the United States is a great challenge for international students. During hard times, Norm was always there providing support and encouragement. His kindness will not be forgotten. 


\section{TABLE OF CONTENTS}

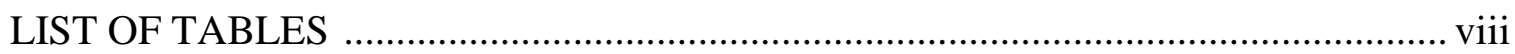

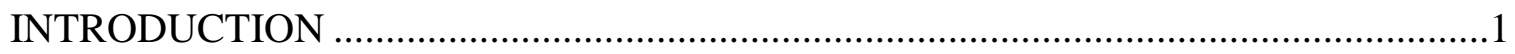

Definition of Pay Satisfaction and Its Dimensionality ...........................................5

Organizational Justice as a Predictor of Pay Satisfaction ......................................

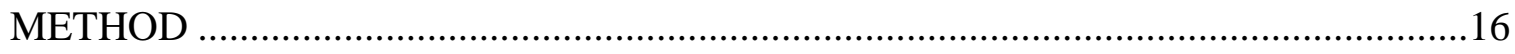

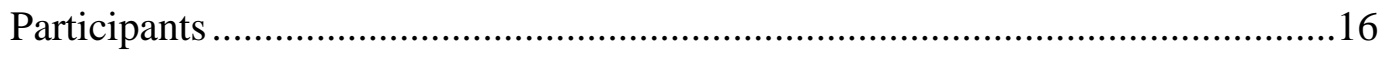

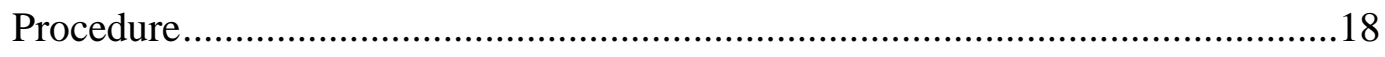

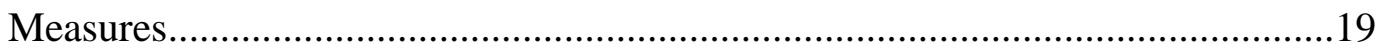

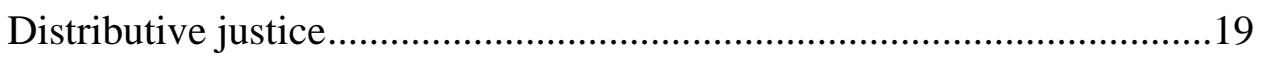

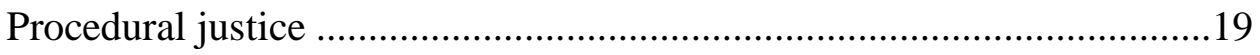

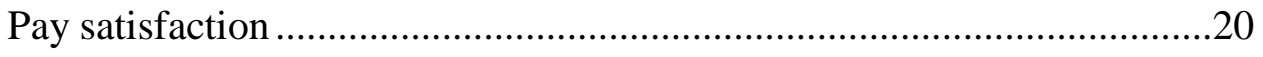

Demographic information..................................................................21

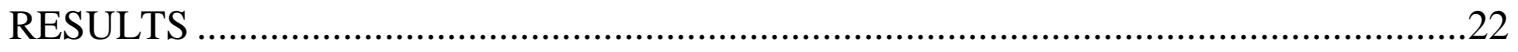

Descriptive Statistics and Pearson Correlations....................................................22

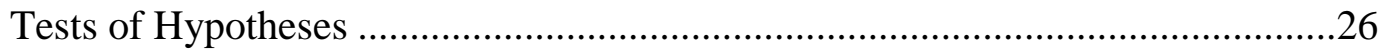

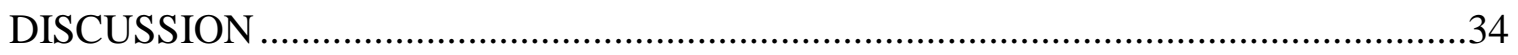

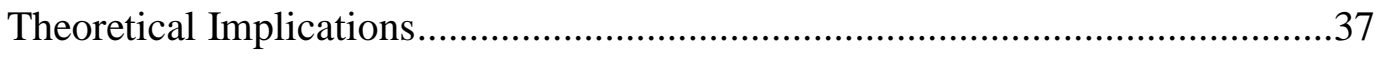

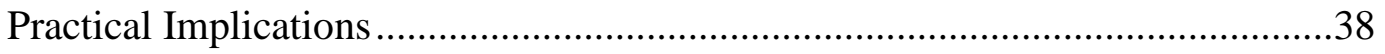

Contributions of the Current Study ....................................................................40

Limitations and Directions for Future Research …………...................................41

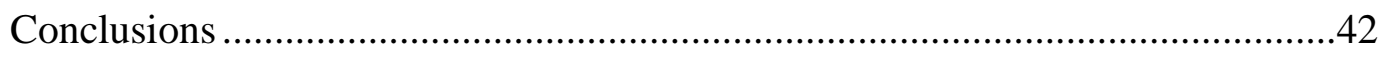




\section{REFERENCES}

APPENDIX 


\section{LIST OF TABLES}

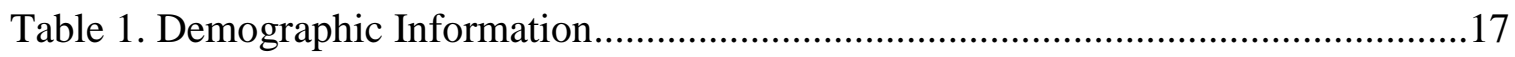

Table 2. Means, Standard Deviations, Pearson Correlations, and Cronbach's Alphas .....25

Table 3. Hierarchical Regression Analysis Summary for the Relationship Between Distributive Justice Perceptions and Procedural Justice Perceptions and Pay Level Satisfaction.

Table 4. Hierarchical Regression Analysis Summary for the Relationship Between Distributive Justice Perceptions and Procedural Justice Perceptions and Pay Structure Satisfaction

Table 5. Hierarchical Regression Analysis Summary for the Relationship Between Distributive Justice Perceptions and Procedural Justice Perceptions and Pay Raises Satisfaction

Table 6. Hierarchical Regression Analysis Summary for the Relationship Between Distributive Justice Perceptions and Procedural Justice Perceptions and Variable Pay Procedure Satisfaction .....

Table 7. Hierarchical Regression Analysis Summary for the Relationship Between Distributive Justice Perceptions and Procedural Justice Perceptions and Benefits Level Satisfaction.

Table 8. Hierarchical Regression Analysis Summary for the Relationship Between Distributive Justice Perceptions and Procedural Justice Perceptions and Benefits Determination Satisfaction.

Table 9. Hierarchical Regression Analysis Summary for the Relationship Between Distributive Justice Perceptions and Procedural Justice Perceptions and Benefits Administration Satisfaction 


\section{Introduction}

According to a Gallup survey, employees in the United States are least satisfied with their pay, followed by their dissatisfaction with retirement plans, promotion chances, and health benefits (Saad, 2012). Only 30\% of the 1,012 surveyed adults were "completely satisfied" with their pay. Pay satisfaction, defined as the degree of positive or negative feelings that people have toward their pay (Miceli \& Lane, 1991), has been shown to be linked to many important organizational outcomes, including work performance (Currall, Towler, Judge, \& Kohn, 2005), turnover intentions (Currall, Towler, Judge, \& Kohn, 2005; Faulk, 2002), work motivation (Ghazanfar, Chuanmin, Khan, \& Bashir, 2011), and organizational commitment (Faulk, 2002; Tang \& Chiu, 2003; Vandenberghe \& Tremblay, 2008). Therefore, if many employees are not satisfied with their pay, such dissatisfaction could have negative consequences for the organization.

Researchers have paid considerable attention to the antecedents of pay satisfaction such as organizational justice (e.g., Terpstra \& Honoree, 2003; Tremblay, Sire \& Balkin, 2000), pay comparisons (e.g., Judge, 1993; Tang, Tang, \& Homaifar, 2006), pay itself (e.g., Tang et al., 2006; Williams, McDaniel, \& Nguyen, 2006), and pay program perceptions (e.g., pay-for-performance, merit pay, bonus program) (e.g., Judge, 1993; Williams et al., 2006). This study focused on organizational justice. Organizational justice, defined as an employee's perception of fairness concerning his or her organization's decisions and actions (Greenburg, 1987), has been shown to play an important role in predicting satisfaction with pay (DeConinck \& Stillwell, 2004; 
Konovsky \& Folger, 1987; Scarpello \& Jones, 1996; Tang \& Sarsfield-Baldwin, 1996; Terpstra \& Honoree, 2003).

However, earlier studies have mainly focused on the relationship between organizational justice and global pay satisfaction or only one dimension of pay satisfaction. One main reason for this is that pay satisfaction was originally considered a global, unidimensional construct (Dyer \& Theriault, 1976; Lawler, 1971, 1981; Weiner, 1980). However, more recent studies have been focusing on the multidimensionality of pay satisfaction (e.g., Heneman \& Schwab, 1985; Judge, 1993; Judge \& Welbourne, 1994). Heneman and Schwab (1985) developed and tested a widely-accepted multidimensional construct of pay satisfaction, including individuals' satisfaction with level of pay, pay raises, benefits, and pay structure/administration. Yet, research is sparse on the relationship between organizational justice and the various dimensions of pay satisfaction (Day, 2011; Jawahar \& Stone, 2011; Sumod \& Premarajan, 2011; Wu \& Wang, 2008).

Furthermore, Heneman and Schwab's (1985) findings suggested that the impact of organizational justice on pay satisfaction might vary depending on the dimension of pay satisfaction studied. For example, these researchers found that assessments of an employee's pay level satisfaction provided little information about his or her benefits satisfaction. Similarly, an employee's satisfaction with other pay components (pay raise, pay structure/administration) was independent of his or her satisfaction with pay level and benefits. Given these findings, Heneman and Schwab suggested that future research should consider the possibility that antecedents of pay satisfaction vary according to the 
different dimensions of pay satisfaction. The present study responded to the call by examining the differential impact of organizational justice on the different dimensions of pay satisfaction.

In addition to exploring the relationship between organizational justice and the different dimensions of pay satisfaction, it is also important to understand which type of justice predicts which dimensions of pay satisfaction better. By understanding which type of justice is a stronger predictor of the sub-dimensions of global pay satisfaction, organizations could adapt their compensation practices to better address employee needs.

Distributive justice, defined as the perceived fairness associated with decision outcomes and resource allocations (Adams, 1965; Colquitt, 2001), and procedural justice, defined as an individual's perception of fairness of the process by which outcomes are decided (Lind \& Tyler, 1988), have been shown to have differing relationships with pay satisfaction (Heneman \& Judge, 2000). Heneman and Judge argued that distributive justice would be a better predictor of outcome-related facets such as pay level, pay raises, and benefits than procedural justice, whereas procedural justice would contribute more to the prediction of process-related facets such as pay structure/administration than distributive justice. However, empirical findings are somewhat inconsistent with their assertion. For example, in some studies (e.g., Day, 2011; Sumod \& Premarajan, 2011), distributive justice has been shown to predict more strongly all dimensions of pay satisfaction, including pay structure/administration. One possible reason for this is that employees under a "fixed pay" system (employees' compensation does not vary based on performance) might view pay system-related facets as a given outcome rather than a 
procedure (Sumod \& Premarajan). In a "variable pay" context (employees receive incentives as part of their compensation based on their performance), a result might be different. Hence, both fixed pay and variable pay need to be considered when studying pay satisfaction dimensions.

Furthermore, Heneman and Schwab's (1985) pay satisfaction construct was developed 30 years ago. Their dimensions might no longer suffice to capture individuals' satisfaction with currently evolved compensation packages (Heneman \& Judge, 2000; Sturman \& Short, 2000). Thus, it is essential to examine the relationship between type of organizational justice and pay satisfaction dimensions that align with more recent compensation practices. Williams, Brower, Ford, Williams, and Carraher's (2008) model of compensation satisfaction takes "variable pay" into consideration, and their measure contains four dimensions for pay satisfaction (level of pay, structure of pay, pay raises, and variable pay procedures) and three dimensions for benefits satisfaction (level of benefits, determination of benefits, and administration of benefits). Williams et al. also encouraged future researchers to use this seven-dimensional construct to study the antecedents and consequences of compensation satisfaction. To the best of the author's knowledge, no studies have examined distributive and procedural justice's relationship with this most recent pay satisfaction construct. Therefore, the present study used Williams et al.'s pay satisfaction construct in examining how justice perceptions would be related to the dimensions of pay satisfaction.

The following sections provide the definition of satisfaction with pay and its dimensionality, the definition of organizational justice and its components, and a 
literature review on the relationship between organizational justice and satisfaction with pay. Finally, the hypotheses that were tested are presented.

\section{Definition of Pay Satisfaction and Its Dimensionality}

As mentioned above, pay satisfaction is defined as the degree of positive or negative feelings that people have toward their pay (Miceli \& Lane, 1991). Prior to 1985, pay satisfaction was considered as a unidimensional construct (Smith, Kendall, \& Hulin, 1969; Weiss, Dawis, England, \& Lofquist, 1967). In some job satisfaction scales, pay satisfaction was also consistently considered to be a one-dimensional component. For example, the compensation satisfaction subscale was used to assess individuals' satisfaction with their pay at work in the Minnesota Satisfaction Questionnaire (MSQ) (Weiss et al., 1967). Similarly, Smith et al. developed the Job Descriptive Index (JDI) to measure whether employees were satisfied with their coworkers, the work itself, pay, promotion opportunities, and supervision. Pay satisfaction was measured unidimensionally.

However, Heneman and Schwab (1985) provided new insights into the nature of pay satisfaction and its measurement by suggesting the multidimensional nature of pay satisfaction. They argued that pay satisfaction consisted of four dimensions: individuals' satisfaction with their pay level, pay raises, benefits, and pay structure/administration. Satisfaction with pay level refers to individuals' degree of satisfaction with their direct compensation (e.g., salary or take-home pay). Satisfaction with pay raises refers to individuals' level of satisfaction with an increase in the amount of their pay. Benefits satisfaction is defined as individuals' satisfaction level with their indirect payment such 
as health insurance and pensions. Finally, satisfaction with pay structure/administration is defined as individuals' degree of satisfaction with the hierarchical relationships established among compensation rates for various jobs and organizational procedures to govern pay-related administration.

Heneman and Judge (2000) pointed out that organizations' pay practices have changed dramatically, such as variable-pay innovations and modifications, greater use of overtime payments, and benefits coverage innovation. Most researchers have fallen behind in this trend by ignoring recent changes. More recently, a few researchers have noticed this gap and suggested to include newer dimensions of pay satisfaction. For example, according to a survey conducted in 1998, lump-sum payments were provided to $24 \%$ of executive-level individuals, $36 \%$ of manager-level individuals, $38 \%$ of technical or professional level workers, $38 \%$ of nonexempt office workers, and $27 \%$ of hourly-paid workers (William M. Mercer, Inc., 1998). Noticing that lump-sum bonuses have become an important part of the total compensation package, Sturman and Short (2000) introduced lump-sum bonus satisfaction as another pay satisfaction dimension. Furthermore, as there has been a trend for employers to implement group incentive plans, including profit sharing and team incentive plans (Welbourne \& Cable, 1995), Fong and Shaffer (2003) suggested that satisfaction with group incentive plans might be an independent component of satisfaction with pay.

Having noticed the extensive changes in the compensation system in recent years, such as the increasing importance of benefits and variable pay programs, Williams et al. (2008) came up with the seven dimensions of pay satisfaction - four dimensions related to 
pay (level of pay, structure of pay, pay raises, and variable pay procedures) and three dimensions related to benefits (benefits level, benefits determination, and benefits administration). Among the four dimensions related to pay, the only dimension that has to do with pay outcomes is pay level satisfaction, referring to employees' satisfaction with amount of pay including base pay salary, and bonuses. The other three dimensions are related to pay procedures - satisfaction with pay structure, satisfaction with pay raises, and satisfaction with variable pay procedures. Williams et al. argued that these three dimensions had to do with how pay was determined, and thus they were included under the pay procedure focus. According to Williams et al., pay structure satisfaction is defined as employees' satisfaction with the hierarchy of pay levels among different positions or jobs within the organization. Pay raise satisfaction refers to employees' satisfaction with how compensation is determined for various employees who have exactly the same job. Variable pay procedures satisfaction is defined as the satisfaction with ways of determining bonuses, incentives, and commissions.

When it comes to satisfaction with benefits dimensions, the only benefits outcome dimension is benefits level satisfaction, referring to satisfaction with the amount of benefits. The other two dimensions are related to benefits procedures - satisfaction with benefits determination and satisfaction with benefits administration. Benefits determination satisfaction is defined as employees' satisfaction with companies' decision-making procedures on benefits coverage, whereas benefits administration satisfaction is defined as employees' satisfaction with policies and processes used to manage their benefits. 
Williams et al. (2008) made a breakthrough on research on pay satisfaction by including a variable pay procedure and two benefits procedure as pay satisfaction dimensions. Although the Pay Satisfaction Questionnaire has been used widely in pay satisfaction-related studies because of its usefulness in understanding satisfaction with different compensation dimensions (Judge \& Welbourne, 1994), it has not kept pace with recent compensation innovations such as the implementation of incentive plans in organizations (Sturman \& Short, 2000). Williams et al. suggested that researchers explore the antecedents and consequences of pay satisfaction by utilizing their newly developed comprehensive compensation satisfaction construct. Besides, using this questionnaire can help better understand employees' reactions and attitudes to an organization's compensation system because it asks about employees' attitudes toward pay and benefits outcomes as well as procedures. The current study responded to Williams et al.'s call by examining the relationship between perceived justice in the workplace and compensation satisfaction by using a more comprehensive pay satisfaction scale.

As mentioned earlier, in pay satisfaction literature, organizational justice has been shown to be important in predicting employees' satisfaction with pay (Heneman \& Judge, 2000). Ensuring organizational justice is particularly important as employees' attitudes toward pay depend on the fairness of pay outcomes, pay procedures, and pay communications (Milkovich \& Newman, 1999). Hence, the following section summarizes literature which links organizational justice to pay satisfaction. 


\section{Organizational Justice as a Predictor of Pay Satisfaction}

Organizational justice is defined as an employee's perception of fairness concerning his or her organization's decisions and actions (Greenburg, 1987). Distributive justice and procedural justice are two types of organizational justice. Distributive justice is defined as the perceived fairness associated with decision outcomes and resource allocations (Adams, 1965; Colquitt, 2001). Because of its focus on outcomes, distributive justice has been proposed to be associated with cognitive and behavioral reactions to particular work outcomes (Cohen-Charash \& Spector, 2001).

Procedural justice is defined as an individual's perception of the fairness of the process by which outcomes are decided (Lind \& Tyler, 1988). Criteria to determine whether procedures and/or policies are fair include (a) consistency (procedures for allocating resources need to maintain consistency across individuals over time); (b) bias suppression (a decision maker's personal bias needs to be suppressed during the allocation process); (c) accuracy (the information used in the allocation process needs to be accurate and correct); (d) correctability (there must be opportunities to make adjustments to an unjust decision); (e) representativeness (all parties' demands and values influenced by the allocation process need to be well-represented); and (f) ethicality (the allocation process needs to be aligned with the ethical and moral standards of the perceiver) (Leventhal, 1980).

Heneman and Judge (2000) have argued that "fairness, whether considered in terms of distributive or procedural justice, is central to pay satisfaction" (p. 88). By reviewing literature on the relationship between justice in the workplace and pay 
satisfaction, Heneman and Judge (2000) found that employees' compensation attitudes were affected by the perceived fairness of their pay and how their pay was determined. Numerous studies have shown the predicting validity of justice with pay satisfaction (e.g., DeConinck \& Stillwell, 2004; Terpstra \& Honoree, 2003; Tremblay, et al., 2000).

As mentioned earlier, most earlier researchers viewed pay satisfaction as a global, unidimensional construct. There have been numerous studies supporting organizational justice as a predictor of global pay satisfaction. For example, in a study of 612 government employees, Scarpello and Jones (1996) investigated the relationship between distributive justice, procedural justice, and satisfaction with pay. They reported that distributive justice was a strong predictor of satisfaction with pay, whereas procedural justice did not have any relationship with pay satisfaction. A "two-factor model" was used to explain their results. The model states that distributive justice is associated with individual level outcomes such as satisfaction with pay, but procedural justice is associated with organizational level outcomes such as organizational commitment (Sweeney \& McFarlin, 1993).

The "two-factor" model has received some support (e.g., DeConinck \& Stilwell, 2004; McFarlin \& Sweeney, 1992). For example, in a study by McFarlin and Sweeney (1992), distributive justice was shown to be more important in predicting personal-related outcomes such as job satisfaction and pay level satisfaction than procedural justice, whereas the reverse was true for two organizational-related outcomes (outcomes related to evaluations of a company) - subordinate's evaluation of supervisors and organizational commitment. Likewise, DeConinck and Stilwell (2004) investigated the relationship 
between organizational justice and two facets of job satisfaction (satisfaction with pay and satisfaction with supervisor). Distributive justice was found to be a predictor of satisfaction with pay, whereas procedural justice did not predict pay satisfaction but was found to be a predictor of supervisor satisfaction. These results showed support for the "two-factor" theory.

Although many studies treated pay satisfaction as a global, unidimensional construct when studying the relationship between organizational justice and pay satisfaction, there were some studies that treated pay satisfaction as a multidimensional construct. Most of these studies, however, took only one dimension of pay satisfaction into consideration when studying the relationship between organizational justice and pay satisfaction. For example, Folger and Konovsky (1989) reported that perceived distributive justice accounted for more variance in employees' satisfaction with pay raises, whereas perceived procedural justice accounted for more variance in outcomes related to the evaluation of an organization such as employees' trust in supervisors and commitment to this organization. However, Fong and Shaffer (2003) found that both distributive justice and procedural justice were significant predictors of group incentive plan satisfaction. Group incentive plan satisfaction refers to the degree of employees' satisfaction with the company's group incentive plan (pay amount, plan design, and plan comparison with others in the company) and was considered to be measuring satisfaction with reward outcomes instead of organization itself. Their results suggest that both distributive justice and procedural justice could predict an employee's satisfaction with pay outcomes such as a company's group incentive plan. 
Davis and Ward (1995) also reported that perceptions of distributive justice accounted for the largest amount of variance in employees' health benefits satisfaction. Other studies, however, discovered that perceptions of procedural justice was better than perceptions of distributive justice in predicting benefits satisfaction (Arnold \& Spell, 2006; Tremblay et al., 2000; Tremblay, Sire, \& Pelchat, 1998). For example, Tremblay et al. (1998) found that perceived procedural justice was a stronger predictor of benefits satisfaction than distributive justice. One possible explanation is that employees usually judge fairness of benefits management (processing claims or adding dependents) more often than they do salary management. Therefore, when employees evaluate their satisfaction with benefits, they may take their judgments of benefits management into consideration. Thus, results probably showed that procedural justice predicted benefits satisfaction better than distributive justice. The Pay Satisfaction Questionnaire used in Tremblay et al.'s study only measured satisfaction with benefits outcomes, and this may not be sufficient to reflect employees' perceptions of benefits. Employees may include their perceptions of benefits administration and processes as well when answering benefits satisfaction-related questions. The comprehensive compensation satisfaction model developed by Williams et al. (2008) helps solve the problem by adding benefits procedure satisfaction as a new pay satisfaction dimension. In order to clarify the role of perceived organizational justice in predicting benefits outcome satisfaction and benefits procedure satisfaction, this study explored the relationship between justice perceptions and benefits satisfaction by using Williams et al.'s scale. 
As mentioned previously, taking the multidimensionality of pay satisfaction into consideration, Heneman and Judge (2000) proposed that distributive justice would be more associated with dimensions pertaining to the amount of compensation obtained (pay level, pay raises, and benefits), whereas procedural justice would be related more to the way in which compensation is administered (pay structure/administration). However, a very limited number of studies (e.g., Day, 2011; Jawahar \& Stone, 2011; Sumod \& Premarajan, 2011; Wu \& Wang, 2008) have examined pay satisfaction as a multidimensional construct and investigated the potential differential relationships of distributive and procedural justice with the various dimensions of pay satisfaction. In some studies, inconsistent with Heneman and Judge's (2000) assertion, perceived distributive justice was found to be a more important predictor of all pay satisfaction dimensions (pay level, pay raises, benefits, structure/administration) than perceived procedural justice (Day, 2011; Sumod \& Premarajan, 2011). Sumod and Premaraja (2011) concluded that employees under a "fixed pay" system might consider pay systemrelated facets as a given outcome. Under the "fixed pay" system, employees' reward does not depend on work performance. Procedural justice might be important in the "variable pay" context, and therefore, it is important to include variable pay aspects in the future. This current study included variable pay procedure satisfaction, which would help fill in the gap in the literature. Results of other studies are inconsistent with Heneman and Judge's (2000) proposition. Wu and Wang (2008) showed that perceived distributive justice was related more to pay satisfaction dimensions (pay level, pay raise, bonus, and pay system) than perceived procedural justice. Jawahar and Stone (2011) showed that 
distributive justice contributed to pay level satisfaction, whereas procedural justice was related to benefits satisfaction, pay raise satisfaction, and pay structure/administration satisfaction. The result that procedural justice was related to outcome satisfaction was attributable to the fact that pay satisfaction measure all the researchers used - Pay Satisfaction Questionnaire - did not distinguish clearly between outcomes and procedures.

Given that the number of studies on the relationship between perceived organizational justice and pay satisfaction as a multidimensional construct are rather limited, and the fact that inconsistent findings exist, this study investigated the relationship between organizational justice and various pay satisfaction dimensions, with an aim to provide further clarification on which justice perceptions are more important to pay satisfaction dimensions. Based on Heneman and Judge's (2000) argument, the following hypotheses were tested.

Hypothesis 1. Pay-related distributive justice perceptions will be a stronger predictor of pay level satisfaction than pay-related procedural justice perceptions.

Hypothesis 2. Pay-related procedural justice perceptions will be a stronger predictor of pay structure satisfaction (2a), pay raise satisfaction (2b), and variable pay procedures satisfaction (2c) than pay-related distributive justice perceptions.

Hypothesis 3. Benefits-related distributive justice perceptions will be a stronger predictor of benefits level satisfaction than benefits-related procedural justice perceptions. 
Hypothesis 4. Benefits-related procedural justice perceptions will be a stronger predictor of benefits determination satisfaction (4a) and benefits administration satisfaction (4b) than benefits-related distributive justice perceptions. 


\section{Method}

\section{Participants}

A total of 229 individuals participated in the study. Those participants who did not complete the entire survey or had a substantial amount of missing responses were excluded from further analyses; therefore, the final sample consisted of 107 participants. Demographic information of the sample is listed in Table 1. The sample consisted of 61 males (57.0\%) and 46 females (43.0\%). Participants' ages ranged from 19 years to 66 years with an average age of 31.51 years $(S D=10.40)$. With regard to ethnicity, $53.3 \%$ of participants were White, 35.5\% Asian/Pacific Islander, 4.7\% Hispanic, 2.8\% African American/Black, $1.9 \%$ multi-ethnic, and $.9 \%$ other. The sample was well educated, with a majority of participants $(71.0 \%)$ having obtained a bachelor's degree or higher.

With respect to their employment status, the majority of participants (77.6\%) worked full-time. They worked on different job types, such as engineering and manufacturing (18.7\%), human resources $(15.0 \%)$, healthcare $(7.5 \%)$, and education (6.5\%). Most participants $(85.0 \%)$ did not work for a unionized organization. In terms of organization size, $28 \%$ of participants worked in an organization with more than 10,000 employees, and $35.4 \%$ of participants worked in relatively small organizations (1 to 200 employees). 
Table 1

Demographic Information $(N=107)$

\begin{tabular}{|c|c|c|}
\hline Demographics & $n$ & $\%$ \\
\hline Age & $M=31.51$ & $S D=10.40$ \\
\hline \multicolumn{3}{|l|}{ Gender } \\
\hline Male & 61 & $57.0 \%$ \\
\hline Female & 46 & $43.0 \%$ \\
\hline \multicolumn{3}{|l|}{ Ethnicity } \\
\hline White & 57 & $53.3 \%$ \\
\hline Hispanic & 5 & $4.7 \%$ \\
\hline African American/Black & 3 & $2.8 \%$ \\
\hline Native American & 1 & $.9 \%$ \\
\hline Asian/Pacific Islander & 38 & $35.5 \%$ \\
\hline Two or more ethnicity & 2 & $1.9 \%$ \\
\hline Other & 1 & $.9 \%$ \\
\hline \multicolumn{3}{|l|}{ Education Level } \\
\hline High school diploma & 19 & $17.8 \%$ \\
\hline Vocational/Trade school diploma & 3 & $2.8 \%$ \\
\hline Associate's Degree & 8 & $7.5 \%$ \\
\hline Bachelor's Degree & 38 & $35.5 \%$ \\
\hline Master's Degree & 35 & $32.7 \%$ \\
\hline Doctorate Degree & 2 & $1.9 \%$ \\
\hline Other & 1 & $.9 \%$ \\
\hline Missing & 1 & $.9 \%$ \\
\hline \multicolumn{3}{|l|}{ Employment Status } \\
\hline Part-time employee & 14 & $13.1 \%$ \\
\hline Full-time employee & 83 & $77.6 \%$ \\
\hline Contract/Temp worker & 10 & $9.3 \%$ \\
\hline \multicolumn{3}{|l|}{ Job Type } \\
\hline Accountancy, banking and finance & 3 & $2.8 \%$ \\
\hline Business, consulting, and management & 5 & $4.7 \%$ \\
\hline Creative arts and design & 4 & $3.7 \%$ \\
\hline Education & 7 & $6.5 \%$ \\
\hline Engineering and manufacturing & 20 & $18.7 \%$ \\
\hline Healthcare & 8 & $7.5 \%$ \\
\hline Hospitality & 1 & $.9 \%$ \\
\hline Human resources & 16 & $15.0 \%$ \\
\hline Information technology & 5 & $4.7 \%$ \\
\hline Law & 1 & $.9 \%$ \\
\hline Media and internet & 1 & $.9 \%$ \\
\hline Public services and administration & 3 & $2.8 \%$ \\
\hline Retail & 6 & $5.6 \%$ \\
\hline Sales & 4 & $3.7 \%$ \\
\hline Social care & 2 & $1.9 \%$ \\
\hline Transport and logistics & 2 & $1.9 \%$ \\
\hline
\end{tabular}


Table 1

Demographic Information $(N=107)$

\begin{tabular}{lrr}
\hline Demographics & $n$ & $\%$ \\
\hline Other & 6 & $5.6 \%$ \\
Missing & 13 & $12.1 \%$ \\
Salary based on commission & & \\
Yes & 4 & $3.7 \%$ \\
No & 102 & $95.3 \%$ \\
Missing & 1 & $.9 \%$ \\
Organization unionization & & \\
Unionized & 15 & $14.0 \%$ \\
Not unionized & 91 & $85.0 \%$ \\
Missing & 1 & $.9 \%$ \\
Size of the organization & & \\
1-50 employees & 21 & $19.6 \%$ \\
$51-200$ employees & 18 & $16.8 \%$ \\
201-500 employees & 6 & $5.6 \%$ \\
$501-1000$ employees & 4 & $3.8 \%$ \\
$1001-5000$ employees & 15 & $14.0 \%$ \\
$5001-10,000$ employees & 13 & $12.2 \%$ \\
$10,001+$ employees & 30 & $28.0 \%$ \\
\hline
\end{tabular}

\section{Procedure}

Data were collected using an online survey. A survey link, along with a short description explaining the study, was sent to the researcher's personal contacts and posted on the researcher's professional networking groups. Upon clicking the survey link, participants were shown an introductory statement of the study stating that it was about examining the relationship between organizational justice and pay satisfaction. By clicking the arrow at the bottom of the page, the participants consented to participate in the survey. After participants completed the survey which measured how satisfied they were with their pay and their perceptions of fairness in the organization, they submitted their responses and received a thank you message on the computer screen for their participation. 


\section{Measures}

Distributive justice. Distributive justice was measured using the scale developed by Colquitt (2001) and reworded by the author. Participants were asked to indicate the extent to which they perceived fairness of pay outcomes in the organization they worked for. Four items were used to measure distributive justice perceptions regarding pay outcomes. Sample items include "Does the pay reflect the effort you put into your work?" and "Is your pay justified given your performance?" Another four items were used to measure distributive justice perceptions regarding benefits outcomes. Sample items include "Do the benefits reflect the effort you put into work?" and "Are your benefits justified given your performance?" Participants were asked to rate the levels of perceived distributive justice on a 5-point Likert scale ranging from 1 (to a small extent) to 5 (to a large extent). Higher scores indicate that individuals perceived higher level of distributive justice in terms of pay and benefits resources allocation in the organization. The Cronbach's alpha for this scale were .87 , and .95 , respectively.

Procedural justice. Procedural justice items used in this study were also from Colquitt (2001) and reworded by the author. Participants were asked to indicate the extent to which they perceived procedural fairness in the organization they worked for. A total of seven items were included to measure perceived procedural justice regarding pay-related procedures. Sample items include "Are pay-related procedures free of bias?" and "Are pay-related procedures based on accurate information?" Cronbach's alpha for this scale was .80. Another set of seven items was used to measure perceived procedural justice regarding benefits-related procedures. Sample items include "Are benefits-related 
procedures free of bias?" and "Are benefits-related procedures based on accurate information?" Respondents were asked to rate their perceptions of procedural fairness on a 5-point scale ranging from 1 (to a small extent) to 5 (to a large extent). Higher scores indicate that individuals perceived greater level of procedural fairness in terms of pay and benefits-related procedures in the organization. The Cronbach's alpha for this scale were .80 , and .88 , respectively.

Pay satisfaction. Pay satisfaction was measured with a 29-item Comprehensive Compensation Satisfaction Questionnaire developed by Williams et al (2008). Each item described various aspects of an individual's pay. Participants were asked to rate their level of satisfaction with different aspects of their compensation. A total of seven pay satisfaction dimensions were included in this scale - four dimensions for pay (pay level, pay structure, pay raises, and variable pay procedures), and three dimensions for benefits (benefits level, benefits determination, and benefits administration).

Pay level satisfaction was measured with four items. A sample item includes "My take home pay." The Cronbach's alpha for this scale was .95. Pay structure satisfaction was measured with five items. A sample item includes "Pay of other jobs in the organization." The Cronbach's alpha for this scale was .88. Pay raises satisfaction was measured with four items. A sample item includes "The size of my most recent raise." The Cronbach's alpha for this scale was .88 . Variable pay procedure satisfaction was measured with three items. A sample item includes "The way bonuses, incentives, and commissions are used in this organization." The Cronbach's alpha for this scale was .91. Benefits level satisfaction was measured with four items. A sample item includes "My 
benefit package." The Cronbach's alpha for this scale was .96. Benefits determination satisfaction was measured with three items. A sample item includes "The say I have in the benefits I receive.” The Cronbach's alpha for this scale was .91. Benefits administration satisfaction was measured with six items. A sample item includes "What I am told about my benefits." The Cronbach's alpha for this scale was .95 .

Participants responded to all of the items on a 5-point Likert scale ranging from 1 (very dissatisfied) to 5 (very satisfied). Higher score indicate that individuals have higher level of satisfaction with a particular dimension of pay satisfaction.

Demographic information. Participants were asked to respond to nine demographic questions, including age, gender, ethnicity, education level, employment status, job type, and the size of their organization. They were also asked whether their salary was based on commission, and whether their organization was unionized. In the present study, the addition of organization unionization and organization size as control variables were attributable to the fact that unionized organizations were positively related with employees' satisfaction with pay (Gomez-Mejia \& Balkin, 1984) and that organization size influenced employees' understanding and perceptions of pay programs (Rasch, 2013). 


\section{Results}

\section{Descriptive Statistics and Pearson Correlations}

Table 2 shows the means, standard deviations, correlations, and Cronbach's alphas among the measured variables. In terms of predictor variables, respondents perceived moderate levels of pay-related distributive justice $(M=3.03, S D=.97)$ and pay-related procedural justice $(M=2.85, S D=.86)$. Furthermore, respondents perceived relatively high level of benefits-related procedural justice $(M=3.61, S D=1.29)$ and benefits-related distributive justice $(M=3.43, S D=1.68)$. With regard to criterion variables, participants were somewhat satisfied with pay level $(M=3.27, S D=.97)$, pay structure $(M=3.20, S D=.80)$, and variable pay procedure $(M=3.17, S D=.93)$. When it came to satisfaction with benefits, somewhat high levels of satisfaction with benefits administration $(M=3.41, S D=1.05)$ and benefits level $(M=3.29, S D=1.17)$ were reported.

Distributive justice perceptions for pay-related outcomes was significantly correlated with procedural justice perceptions for pay-related procedures $(r=.52, p$ $<.01$ ), indicating that the fairer individuals perceived their pay-related outcomes, the fairer they perceived the procedures for such outcomes. Likewise, distributive justice perceptions for benefits-related outcomes were significantly related to procedural justice perceptions for benefits-related procedures $(r=.70, p<.01)$, indicating that the fairer individuals perceived benefits-related outcomes, the fairer they perceived the procedures for such benefits-related outcomes. Furthermore, distributive justice perceptions for payrelated outcomes were positively correlated with distributive justice perceptions for 
benefits-related outcomes $(r=.33, p<.01)$. Likewise, procedural justice perceptions for pay-related outcomes were positively related to procedural justice perceptions for benefits-related procedures $(r=.57, p<.01)$.

The four pay-related satisfaction dimensions (pay level, pay raises, pay structure, variable pay procedure) were highly correlated with one another, with correlations ranging from .44 to .59 . These results showed that if one was satisfied with a particular pay-related dimension, he or she was also likely to be satisfied with the other pay-related dimensions. Satisfaction with these four pay-related dimensions was also significantly and positively related to distributive justice perceptions and procedural justice perceptions for pay-related outcomes. These results indicated that those who perceived pay-related outcomes and procedures were fairer became more satisfied with pay level, pay structure, pay raise, and variable pay procedures. The highest correlation obtained was between distributive justice perceptions for pay-related outcomes and pay level satisfaction $(r=.57, p<.01)$, and between procedural justice perceptions for pay-related procedures and pay structure satisfaction $(r=.57, p<.01)$.

All three benefits-related satisfaction dimensions were also significantly correlated with each other, with correlations ranging from .72 to .78 . These results showed that if one was satisfied with one dimension of benefits, he or she was also satisfied with the other benefits' dimensions. These benefits-related satisfaction dimensions were also significantly and positively correlated with benefits-related distributive justice and procedural justice. These results indicated that those who perceived outcomes and procedures pertaining benefits as fairer, they became more 
satisfied with these benefits-related dimensions of pay. The highest correlation obtained was between benefits-related procedural justice perceptions and benefits determination satisfaction $(r=.70, p<.01)$.

With regard to the control variables, organization unionization was correlated to benefits outcome satisfaction $(r=.23, p<.05)$ and benefits determination satisfaction $(r$ $=.20, p<.05)$, such that those in unionized organizations were more satisfied with benefits outcomes and benefits determination than those in non-unionized organizations. Organization size was positively related to pay level satisfaction $(r=.20, p<.05)$ and to all benefits satisfaction dimensions, including benefits level satisfaction $(r=.33, p<.01)$, benefits determination satisfaction $(r=.39, p<.01)$, and benefits administration satisfaction $(r=.32, p<.01)$, indicating that the larger the organizations individuals worked for, the more satisfied they were with their pay level, benefits level, and benefitsrelated procedures in the organizations. 
Table 2

Means, Standard Deviations, Pearson Correlations, and Cronbach's Alphas $(N=107)$

\begin{tabular}{|c|c|c|c|c|c|c|c|c|c|c|c|c|c|c|c|}
\hline Measure & Mean & SD & 1 & 2 & 3 & 4 & 5 & 6 & 7 & 8 & 9 & 10 & 11 & 12 & 13 \\
\hline $\begin{array}{l}\text { 1. Distributive justice of } \\
\text { pay-related outcomes }\end{array}$ & 3.03 & .97 & $(.87)$ & & & & & & & & & & & & \\
\hline $\begin{array}{l}\text { 2. Procedural justice of } \\
\text { pay-related procedures }\end{array}$ & 2.85 & .86 & $.52 * *$ & $(.80)$ & & & & & & & & & & & \\
\hline $\begin{array}{l}\text { 3. Distributive justice of } \\
\text { benefits-related outcomes }\end{array}$ & 3.43 & 1.68 & $.33 * *$ & $.40 * *$ & $(.95)$ & & & & & & & & & & \\
\hline $\begin{array}{l}\text { 4. Procedural Justice of } \\
\text { benefits-related } \\
\text { procedures) }\end{array}$ & 3.61 & 1.29 & .18 & $.57 * *$ & $.70 * *$ & $(.88)$ & & & & & & & & & \\
\hline 5. Pay level satisfaction & 3.27 & .97 & $.57 * *$ & $.43^{* *}$ & $.19 *$ & .19 & $(.95)$ & & & & & & & & \\
\hline $\begin{array}{l}\text { 6. Pay structure } \\
\text { satisfaction }\end{array}$ & 3.20 & .80 & $.52 * *$ & $.57 * *$ & $.20 *$ & $.30 * *$ & $.58 * *$ & $(.88)$ & & & & & & & \\
\hline 7. Pay raises satisfaction & 3.07 & .94 & $.48 * *$ & $.48 * *$ & .15 & $.21 *$ & $.44 * *$ & $.59 * *$ & $(.88)$ & & & & & & \\
\hline $\begin{array}{l}\text { 8. Variable pay procedure } \\
\text { satisfaction }\end{array}$ & 3.17 & .93 & $.48 * *$ & $.47 * *$ & $.22 *$ & $.27^{* *}$ & $.50 * *$ & $.58 * *$ & $.53 * *$ & $(.91)$ & & & & & \\
\hline $\begin{array}{l}\text { 9. Benefits level } \\
\text { satisfaction }\end{array}$ & 3.29 & 1.17 & $.25 *$ & $.36 * *$ & $.60 * *$ & $.60 * *$ & $.38 * *$ & $.41 * *$ & $.31 * *$ & $.43^{* *}$ & $(.96)$ & & & & \\
\hline $\begin{array}{l}\text { 10. Benefits } \\
\text { determination satisfaction }\end{array}$ & 3.05 & 1.08 & .19 & $.38 * *$ & $.60 * *$ & $.70 * *$ & $.39 * *$ & $.41 * *$ & $.35^{* *}$ & $.38 * *$ & $.78 * *$ & $(.91)$ & & & \\
\hline $\begin{array}{l}11 . \text { Benefits } \\
\text { administration } \\
\text { satisfaction }\end{array}$ & 3.41 & 1.05 & .17 & $.42 * *$ & $.54 * *$ & $.61^{* *}$ & $.34 * *$ & $.36 * *$ & $.31 * *$ & $.33 * *$ & $.72 * *$ & $.72 * *$ & $(.95)$ & & \\
\hline $\begin{array}{l}\text { 12. Organization } \\
\text { unionization }\end{array}$ & - & - & -.09 & -.06 & .10 & .09 & -.01 & -.07 & -.05 & -.02 & $.23^{*}$ & $.20 *$ & .17 & $-.19 *$ & \\
\hline 13. Organization size & - & - & .14 & $.23 *$ & $.37 * *$ & $.39 * *$ & $.20 *$ & .08 & .01 & .02 & $.33 * *$ & $.39 * *$ & $.32 * *$ & .06 & .02 \\
\hline
\end{tabular}

Reliability coefficients (alpha) presented on the diagonal. 


\section{Tests of Hypotheses}

Hierarchical linear regressions were utilized to test the four hypotheses. For each regression analysis, control variables (organizational size and organization unionization) were entered at Step 1. Distributive justice perceptions and procedural justice perceptions were entered at Step 2. A t-test was run to examine the difference in the beta-weights associated with distributive justice perceptions and procedural justice perceptions to test each hypothesis.

Hypothesis 1 stated that pay-related distributive justice perceptions would be a stronger predictor of pay level satisfaction than pay-related procedural justice. Results

are shown in Table 3. The control variables did not predict pay level satisfaction $\left(R^{2}\right.$ $=.04, p=.17)$. Distributive justice perceptions and procedural justice perceptions together explained additional $35 \%$ of the variance in pay level satisfaction $\left(\Delta R^{2}=.35, p\right.$ $<.001)$ above and beyond the variance explained by the control variables. The results of a t-test showed that the difference in the beta weights between distributive justice perceptions and procedural justice perceptions was significant $(t(97)=3.50, p<.05)$. These results showed that distributive justice perceptions $(\beta=.50, p<.001)$ predicted pay level satisfaction more strongly than procedural justice $(\beta=.17, p=.07)$. Thus, Hypothesis 1 was supported. 
Table 3

Hierarchical Regression Analysis Summary for the Relationship Between Distributive Justice Perceptions and Procedural Justice Perceptions and Pay Level Satisfaction $(N=$ 102)

\begin{tabular}{lllll}
\hline Steps and Variables & $\mathrm{R}^{2}$ & $\Delta \mathrm{R}^{2}$ & $\mathrm{R}$ & $\beta$ \\
\hline Step 1: & & & & \\
$\quad$ Organization Unionization & .04 & .04 & .19 & -.01 \\
$\quad$ Organization Size & & & & .19 \\
$\begin{array}{l}\text { Step 2: } \\
\quad \text { Distributive Justice }\end{array}$ & $.39^{* * *}$ & $.35^{* * *}$ & $.63^{* * *}$ & $.50^{* * *}$ \\
$\quad$ Procedural Justice & & & & .17 \\
\hline
\end{tabular}

Note. $* p<.05, * * p<.01, * * * p<.001$. Betas reported at time of entry.

Hypothesis 2 posited that procedural justice perceptions for pay-related procedures would be a stronger predictor of pay structure satisfaction (2a), pay raises satisfaction (2b), and variable pay procedure satisfaction (2c) than distributive justice perceptions for pay-related procedures. Table 4 displays results pertaining to pay structure satisfaction $(\mathrm{H} 2 \mathrm{a})$. Results showed that the control variables did not predict pay structure satisfaction $\left(R^{2}=.02, p=.45\right)$. Distributive justice perceptions and procedural justice perceptions together explained additional $38 \%$ of the variance in pay structure satisfaction $\left(\Delta R^{2}=.38, p<.001\right)$, above and beyond the variance explained by the control variables. The results of a t-test showed that the beta weight difference between distributive justice perceptions and procedural justice perceptions was not significant $(t(98)=-.99, p>.05)$. There was no statistically significant difference in predicting pay structure satisfaction between distributive justice perceptions $(\beta=.32, p<.01)$, and procedural justice perceptions $(\beta=.41, p<.001)$. Procedural justice perceptions were not a stronger predictor of pay structure satisfaction than distributive justice perceptions. 
Instead, both justice perceptions significantly and equally predicted pay structure satisfaction. Thus, Hypothesis 2a was not supported.

Table 4

Hierarchical Regression Analysis Summary for the Relationship Between Distributive Justice Perceptions and Procedural Justice Perceptions and Pay Structure Satisfaction $(N=103)$

\begin{tabular}{lllll}
\hline Steps and Variables & $\mathrm{R}^{2}$ & $\Delta \mathrm{R}^{2}$ & $\mathrm{R}$ & $\beta$ \\
\hline $\begin{array}{l}\text { Step 1: } \\
\quad \text { Organization Unionization }\end{array}$ & .02 & .02 & .13 & -.09 \\
$\quad$ Organization Size & & & & .09 \\
$\begin{array}{l}\text { Step 2: } \\
\quad \text { Distributive Justice }\end{array}$ & $.40^{* * *}$ & $.38^{* * *}$ & $.63^{* * *}$ & $.32^{* *}$ \\
$\quad$ Procedural Justice & & & & $.41^{* * *}$ \\
\hline
\end{tabular}

Note. $* p<.05, * * p<.01, * * * p<.001$. Betas reported at time of entry.

Table 5 shows results for pay raises satisfaction $(\mathrm{H} 2 \mathrm{~b})$. The control variables did not predict pay raises satisfaction $\left(R^{2}=.01, p=.52\right)$. Distributive justice perceptions and procedural justice perceptions together explained additional $33 \%$ of the variance in pay raises satisfaction $\left(\Delta R^{2}=.33, p<.001\right)$, above and beyond the variance explained by the control variables. The result of a t-test showed that the beta weight difference between distributive justice perceptions and procedural justice perceptions was not significant $(t(97)=.21, p>.05)$, indicating that there was no statistically significant difference in predicting pay raises satisfaction between distributive justice perceptions $(\beta=.35, p$ $<.001)$, and procedural justice perceptions $(\beta=.33, p<.01)$. Distributive justice perceptions and procedural justice perceptions equally predicted pay raises satisfaction. These results showed that Hypothesis $2 \mathrm{~b}$ was not supported. 
Table 5

Hierarchical Regression Analysis Summary for the Relationship Between Distributive Justice Perceptions and Procedural Justice Perceptions and Pay Raises Satisfaction ( $N=$ 102)

\begin{tabular}{lllll}
\hline Steps and Variables & $\mathrm{R}^{2}$ & $\Delta \mathrm{R}^{2}$ & $\mathrm{R}$ & $\beta$ \\
\hline Step 1: & & & & \\
$\quad$ Organization Unionization & .01 & .01 & .12 & -.12 \\
$\quad$ Organization Size & & & & -.00 \\
$\begin{array}{l}\text { Step 2: } \\
\quad \text { Distributive Justice }\end{array}$ & $.34^{* * *}$ & $.33^{* * *}$ & $.59^{* * *}$ & $.35^{* * *}$ \\
$\quad$ Procedural Justice & & & & $.33^{* *}$ \\
\hline
\end{tabular}

Note. $* p<.05, * * p<.01, * * * p<.001$. Betas reported at time of entry.

Table 6 shows results for variable pay procedure satisfaction $(\mathrm{H} 2 \mathrm{c})$. Results showed that the control variables did not have a significant effect on pay procedure satisfaction $\left(R^{2}=.00, p=.96\right)$. Distributive justice perceptions and procedural justice perceptions together explained additional $31 \%$ of the variance in the variable pay procedure satisfaction $\left(\Delta R^{2}=.31, p<.001\right)$, above and beyond the variance explained by the control variables. The result of a t-test showed that the beta weight difference between distributive justice and procedural justice was not significant $(t(98)=.21$, $p>.05)$, indicating that there was no statistically significant difference in predicting variable pay procedure satisfaction between distributive justice perceptions $(\beta=.34, p$ $<.01)$, and procedural justice perceptions $(\beta=.32, p<.01)$. Distributive justice perceptions and procedural justice perceptions equally predicted variable pay procedure satisfaction. These results indicate that Hypothesis $2 \mathrm{c}$ was not supported. Overall, none of Hypothesis 2 was supported. 
Table 6

Hierarchical Regression Analysis Summary for the Relationship Between Distributive Justice Perceptions and Procedural Justice Perceptions and Variable Pay Procedure Satisfaction $(N=103)$

\begin{tabular}{lllll}
\hline Steps and Variables & $\mathrm{R}^{2}$ & $\Delta \mathrm{R}^{2}$ & $\mathrm{R}$ & $\beta$ \\
\hline Step 1: & & & & \\
$\quad \begin{array}{l}\text { Organization Unionization } \\
\text { Organization Size }\end{array}$ & .00 & .00 & .03 & -.01 \\
$\begin{array}{l}\text { Step 2: } \\
\quad \text { Distributive Justice }\end{array}$ & $.31^{* * *}$ & $.31^{* * *}$ & $.56^{* * * *}$ & .03 \\
$\quad$ Procedural Justice & & & & $.34^{* * *}$ \\
\hline
\end{tabular}

Note. $* p<.05, * * p<.01, * * * p<.001$. Betas reported at time of entry.

Hypothesis 3 stated that distributive justice perceptions for benefits-related outcomes would be a stronger predictor of benefits level satisfaction than procedural justice perceptions for benefits-related procedures. Results are shown in Table 7. Results showed that the control variables explained $15 \%$ of the variance in benefits level satisfaction $\left(R^{2}=.15, p<.001\right)$. These results show that those who worked in a unionized organization and those in a larger organization were more likely to be satisfied with their benefits level. Distributive justice perceptions and procedural justice perceptions together explained additional $30 \%$ of the variance in benefits level satisfaction $\left(\Delta R^{2}=.30, p<.001\right)$, above and beyond the variance explained by the control variables. The results of a t-test showed that beta weight difference between distributive justice perceptions and procedural justice perceptions was not significant $(t(97)=-.43$, $p>.05)$, indicating that distributive justice perceptions $(\beta=.31, p<.01)$, and procedural justice perceptions $(\beta=.35, p<.01)$, equally contributed to the prediction of benefits level satisfaction. Therefore, Hypothesis 3 was not supported. 
Table 7

Hierarchical Regression Analysis Summary for the Relationship Between Distributive Justice Perceptions and Procedural Justice Perceptions and Benefits Level Satisfaction $(N=102)$

\begin{tabular}{lllll}
\hline Steps and Variables & $\mathrm{R}^{2}$ & $\Delta \mathrm{R}^{2}$ & $\mathrm{R}$ & $\beta$ \\
\hline Step 1: & & & & \\
$\quad \begin{array}{l}\text { Organization Unionization } \\
\text { Organization Size }\end{array}$ & $.15^{* * *}$ & $.15^{* * *}$ & $.39^{* * *}$ & $.23^{*}$ \\
$\begin{array}{l}\text { Step 2: } \\
\quad \text { Distributive Justice }\end{array}$ & $.45^{* * *}$ & $.30^{* * *}$ & $.67^{* * * *}$ & $.31^{* *}$ \\
$\quad$ Procedural Justice & & & & $.35^{* *}$ \\
\hline
\end{tabular}

Note. $* p<.05, * * p<.01, * * * p<.001$. Betas reported at time of entry.

Hypothesis 4 posited that procedural justice perceptions for benefits-related

procedures would be a stronger predictor of benefits determination satisfaction (4a) and benefits administration satisfaction (4b) than distributive justice for benefits-related outcomes. Table 8 shows results pertaining to benefits determination satisfaction (H4a). Control variables explained $19 \%$ of the variance in benefits determination satisfaction $\left(R^{2}\right.$ $=.19, p<.001)$. Employees who worked in unionized organizations and those in larger organizations were more likely to be satisfied with how their benefits were determined. Both distributive justice perceptions and procedural justice perceptions explained additional $37 \%$ of the variance in benefits determination satisfaction $\left(\Delta R^{2}=.37, p\right.$ $<.001$ ), above and beyond the variance explained by the control variable. The result of a t-test showed that beta weight difference between distributive justice perceptions and procedural justice perceptions was significant $(t(97)=-3.78, p<.05)$, indicating that perceived procedural justice $(\beta=.52, p<.001)$, was a significantly stronger predictor of benefits determination satisfaction than perceived distributive justice $(\beta=.19, p<.05)$. Therefore, Hypothesis 4a was supported. 
Table 8

Hierarchical Regression Analysis Summary for the Relationship Between Distributive Justice Perceptions and Procedural Justice Perceptions and Benefits Determination Satisfaction $(N=102)$

\begin{tabular}{lllll}
\hline Steps and Variables & $\mathrm{R}^{2}$ & $\Delta \mathrm{R}^{2}$ & $\mathrm{R}$ & $\beta$ \\
\hline Step 1: & & & & \\
$\quad$ Organization Unionization & $.19^{* * *}$ & $.19^{* * *}$ & $.43^{* * *}$ & $.21^{*}$ \\
$\quad$ Organization Size & & & & $.37^{* * *}$ \\
$\begin{array}{l}\text { Step 2: } \\
\quad \text { Distributive Justice }\end{array}$ & $.56^{* * *}$ & $.37^{* * *}$ & $.75^{* * *}$ & $.19^{*}$ \\
$\quad$ Procedural Justice & & & & $.52^{* * *}$ \\
\hline
\end{tabular}

Note. $* p<.05, * * p<.01, * * * p<.001$. Betas reported at time of entry.

Table 9 shows results pertaining to benefits administration satisfaction (H4b).

Control variables explained $16 \%$ of the variance in benefits administration satisfaction $\left(R^{2}=.16, p<.001\right)$. Employees who worked in unionized organizations and those in larger organizations were more likely to be satisfied with how their benefits were administered by the organizations. Distributive justice perceptions and procedural justice perceptions together explained additional $30 \%$ of the variance in benefits administration satisfaction $\left(\Delta R^{2}=.30, p<.001\right)$, above and beyond the variance explained by the control variable. The result of a t-test showed that the beta weight difference between distributive justice and procedural justice was significant $(t(95)=-2.25, p<.05)$, showing that perceived procedural justice $(\beta=.43, p<.001)$, was a significantly stronger predictor of benefits administration satisfaction than perceived distributive justice $(\beta=.22, p$ $<.05)$. These results showed support for Hypothesis 4b. Overall, Hypothesis 4 was supported for benefits determination satisfaction and benefits administration satisfaction. 
Table 9

Hierarchical Regression Analysis Summary for the Relationship Between Distributive Justice Perceptions and Procedural Justice Perceptions and Benefits Administration Satisfaction $(N=100)$

\begin{tabular}{lllll}
\hline Steps and Variables & $\mathrm{R}^{2}$ & $\Delta \mathrm{R}^{2}$ & $\mathrm{R}$ & $\beta$ \\
\hline Step 1: & & & & \\
$\quad$ Organization Unionization & $.16^{* * *}$ & $.16^{* * *}$ & $.40^{* * *}$ & $.25^{*}$ \\
$\quad$ Organization Size & & & & $.31^{* *}$ \\
Step 2: & & & & \\
$\quad$ Distributive Justice & $.46^{* * *}$ & $.30^{* * *}$ & $.68^{* * *}$ & $.22^{*}$ \\
$\quad$ Procedural Justice & & & & $.43^{* * *}$ \\
\hline
\end{tabular}

Note. $* p<.05, * * p<.01, * * * p<.001$. Betas reported at time of entry.

In sum, Hypothesis 1 was supported that perceived distributive justice for payrelated outcomes was a stronger predictor of pay level satisfaction than perceived procedural justice for pay-related procedures. None of Hypothesis 2 was supported and results showed that both pay-related distributive justice and procedural justice equally contributed to the prediction of pay structure, pay raises, and variable pay procedure. Hypothesis 3 was not supported that both perceived distributive justice for benefitsrelated outcomes and perceived procedural justice for benefits-related procedures equally contributed to the prediction of benefits level satisfaction. Overall, Hypothesis 4 was supported such that perceived procedural justice was a significantly stronger predictor of benefits determination satisfaction and benefits administration satisfaction than perceived distributive justice. 


\section{Discussion}

The relationship between organizational justice and pay satisfaction has drawn a considerable amount of research attention (e.g., Terpstra \& Honoree, 2003; Tremblay et al., 2000). However, earlier studies have mainly focused on the relationship between organizational justice and global pay satisfaction or only one dimension of pay satisfaction (Smith et al., 1969; Weiss et al., 1967). Heneman and Schwab (1985) argued that researchers should consider the effects of different dimensions of pay satisfaction on their relationships with organizational justice. Yet, the number of studies that examined the relationship between organizational justice and the various dimensions of pay satisfaction is rather limited (Day, 2011; Jawahar \& Stone, 2011; Sumod \& Premarajan, 2011; Wu \& Wang, 2008). Furthermore, researchers (Heneman \& Judge, 2000; Sturman \& Short, 2000) asserted that the commonly used Pay Satisfaction Questionnaire (Heneman \& Schwab, 1985) should keep pace with modern compensation changes.

Williams et al.'s (2008) Compensation Satisfaction questionnaire takes into consideration new pay practices such as variable pay.

Therefore, this study took all of the above concerns into consideration and examined the relationship between organizational justice (distributive justice and procedural justice) and the various dimensions of pay satisfaction using Williams et al.'s (2008) scale. Additionally, as Heneman and Judge (2000) argued that distributive justice would be a stronger predictor of outcome-related factors such as pay level, pay raises, and benefits, whereas procedural justice would contribute more to the prediction of process-related pay satisfaction such as pay structure/administration, the study tested 
which type of justice perceptions would predict which dimensions of pay satisfaction better.

Hypothesis 1 stated that perceived distributive justice for pay-related outcomes would be a stronger predictor of pay level satisfaction than perceived procedural justice for pay-related procedures. Consistent with Hypothesis 1, results showed that perceived distributive justice predicted pay level satisfaction more strongly than perceived procedural justice. These results showed that the higher level of distributive justice in pay resources allocations significantly predicted employees' satisfaction with their pay levels. These results are consistent with Heneman and Judge's (2000) proposition that distributive justice, focusing on the degree to which individuals perceive their compensation as fair, would be a better predictor of satisfaction with the amount of compensation obtained than procedural justice.

Hypothesis 2 stated that perceived procedural justice for pay-related procedures would be a stronger predictor of pay structure satisfaction (2a), pay raises satisfaction (2b), and variable pay procedure satisfaction (2c) than perceived distributive justice for pay-related outcomes. Results showed that both perceived distributive justice and procedural justice were significant predictors and that perceived procedural justice was not a stronger predictor of these procedure-related pay satisfaction than perceived distributive justice. These results show that perceived fairness in pay resources allocations and perceived fairness in pay-related procedures equally contributed to the prediction of satisfaction with pay structure, pay raises, and variable pay procedure. Therefore, these results did not support Hypothesis 2. 
One potential explanation for the lack of support for the hypothesis is that perceived distributive justice for pay-related outcomes was significantly related to perceived procedural justice for pay-related procedures. Employees who perceived high levels of fairness in pay-related outcomes might also consider fairness in pay-related procedures. Perhaps, if employees perceive that pay-related outcomes are fair, they might think that the procedures to come up with these pay-related outcomes are also fair, or vice versa.

Hypothesis 3 stated that perceived benefits-related distributive justice would be a stronger predictor of benefits level satisfaction than perceived benefits-related procedural justice. However, results showed that both perceived benefits-related distributive justice and procedural justice were equally significant predictors of benefits level satisfaction. Employees who perceived higher levels of fairness in benefits outcomes and procedures were more satisfied with their benefits levels. Hence, Hypothesis 3 was not supported. The lack of support for the hypothesis might be due to the fact that employees had limited influence over their benefits - organizations are the ones that distribute, decide, and administer benefits. Thus, free-of-bias benefits procedures inside the organization may become as important to employees as the benefits package received. Employees feel appreciation when they perceive fair benefits procedures in an organization. Hence, both fair benefits procedures and outcomes can elicit a similar level of satisfaction with the received benefits package. In other words, employees may not differentiate fairness in benefits outcomes and procedures when evaluating their benefits packages. 
Hypothesis 4a stated that perceived benefits-related procedural justice would be a stronger predictor of benefits determination satisfaction (4a) and benefits administration satisfaction (4b) than perceived benefits-related distributive justice. Results showed that both perceived distributive justice and procedural justice were significant predictors of benefits determination and benefits administration satisfaction, but the predicting power of procedural justice was stronger than that of distributive justice. These results showed support for Hypothesis 4. Employees who perceived a higher level of fairness in benefits outcomes and procedures were more satisfied with how benefits were determined and administered in their organization. Additionally, perceived fairness in benefits procedures mattered more to employees' satisfaction with benefits determination and benefits administration than fairness in benefits outcomes. One possible explanation is that allowing employees to have a choice about which benefits they can pick gives employees an opportunity to get involved in benefits determination, and the administration process might increase their positive attitudes toward how benefits are determined and administered in an organization.

\section{Theoretical Implications}

The current study tested the proposition by Heneman and Judge (2000) that distributive justice would be more associated with compensation outcome dimensions, whereas procedural justice would relate more with compensation-related processes. Results of the study showed that perceived pay-related distributive justice was a stronger predictor of pay level satisfaction than perceived pay-related procedural justice.

Furthermore, perceived benefits-related procedural justice did predict satisfaction with 
benefits procedures (benefits determination and administration) better than perceived benefits-related distributive justice. The current study offers a better understanding of how the relationships between organizational justice type and pay satisfaction dimensions are like. Although there were studies on the relationship between organizational justice and global pay satisfaction or one dimension of pay satisfaction, a very limited number of studies (e.g., Day, 2011; Jawahar \& Stone, 2011; Wu \& Wang, 2008; Sumod \& Premarajan, 2011) have explored potential differential relationships of distributive and procedural justice with various dimensions of pay satisfaction dimensions. Therefore, the results of the current study expanded the research on the differential predicting roles of organizational justice type on various pay satisfaction dimensions.

\section{Practical Implications}

The results of this study indicate that pay-related distributive justice perceptions were a stronger predictor of pay level satisfaction than pay-related procedural justice perceptions. The higher the level of fairness in pay outcomes employees perceived, the higher the satisfaction they had with their pay level. Thus, when distributing pay outcomes (e.g. salary, take-home pay), organizations need to maintain high level of distributive justice in order to have employees who are satisfied with their pay level. For instance, organizations need to ensure that employees' pay reflect the effort they put into work and their contributions to the organization, and ensure that employees' pay outcomes are justified given their performance so that employees can have a high level of satisfaction with their pay outcomes. 
Results also indicate that both pay-related distributive justice perceptions and payrelated procedural justice perceptions significantly and equally contributed to pay structure satisfaction, pay raises satisfaction, and variable pay procedure satisfaction. Employees who perceive a high level of fairness in pay outcomes and pay procedures are likely to have a high level of satisfaction with pay structure, pay raises, and variable pay procedures. However, perceived fairness of pay outcomes and pay procedures did not make any difference in predicting an employee's level of satisfaction with pay structure, pay raises, and variable pay procedures. Organizations need to ensure a high level of pay fairness, including ensuring that employees' pay reflect their hard efforts and their contributions as well as that pay-related procedures are fair to all employees.

Furthermore, results showed that both perceived benefits-related distributive justice and procedural justice equally contributed to benefits level satisfaction. Employees who perceive higher levels of fairness in benefits outcomes and benefits procedures are more likely to be satisfied with their benefits levels. Organizations could increase their fairness when distributing benefits package and making benefits decisions. For instance, organizations could focus on maintaining fairness of benefits values employees receive, increasing employee involvement when determining what benefits to offer, and making a benefits administration process transparent to all employees.

Finally, the results showed that procedural justice perceptions were a stronger predictor of benefits determination satisfaction and benefits administration satisfaction than distributive justice perceptions. When organizations make decisions about employee benefits or administer various benefits, it is essential for organizations to use 
fair procedures, including making benefits-related procedures known to employees, giving employees opportunities to voice their opinions about these procedures and ensuring that these procedures are free of bias and based on accurate information.

\section{Contributions of the Current Study}

The current study has several contributions that are worth mentioning. First, the study surveyed respondents from a wide range of background. Participants had different education levels and were from small to large organizations. Thus, the results obtained might be generalizable across different education levels and different organization size. Second, a majority of studies on the relationship between organizational justice and pay satisfaction only focused on global pay satisfaction or one dimension of pay satisfaction. This study, however, included multiple pay satisfaction dimensions, providing a better understanding of how justice perceptions predicted various pay satisfaction dimensions. The addition of dimensions such as variable pay procedure satisfaction ensure that the pay satisfaction questionnaire used in this study kept pace with the most recent compensation package changes. By using the questionnaire developed by Williams et al. (2008), the study provided insights into variable pay procedure satisfaction and shows that employees who perceive a high level of fairness in pay outcomes and pay procedures are more satisfied with variable pay procedures.

Additionally, this study contributed to the literature by exploring the differential relationships of distributive justice perceptions and procedural justice perceptions with pay satisfaction dimensions. Pay-related distributive justice perceptions and procedural justice perceptions were found to have differential relationships with pay level 
satisfaction. Benefits-related distributive justice perceptions and procedural justice perceptions were found to have differential relationships with benefits determination satisfaction and benefits administration satisfaction.

\section{Limitations and Directions for Future Research}

Despite its strengths, this study has a few limitations that can be addressed by future research. From a methodology point of view, this study collected data using a selfreport questionnaire. Therefore, this study may have common method bias (Podsakoff, MacKenzie, Lee, \& Podsakoff, 2003). The researcher measured all the variables using a common method. Thus, the significant relationships in this study might have been inflated due to bias. For instance, some participants may tend to maintain consistency when answering similar questions such as justice perceptions in an organization. Chang, Witteloostuijn, and Eden (2010) suggested that a complicated model with non-linear interaction is less likely to guide participants to maintain consistency than a simple model. Thus, future researchers can increase the complexity of the research model by adding mediating, moderating or non-linear effects to reduce participants' tendency to maintain consistency.

Additionally, this study used a correlational design. No conclusion about causal relationships can be drawn from this study. A longitudinal study can be conducted in order to figure out the causal relationship between organizational justice and pay satisfaction. For instance, researchers can measure participants' perceived fairness of reward outcomes and reward procedures and compensation satisfaction repeatedly over 
long periods of time. This type of study has more power to detect causal relationship than a correlational design.

Another weakness of this study is that a significant amount of data was deleted more than half of the data collected was not usable. This could be due to the fact that the survey was distributed massively to potential participants via the internet. Many potential participants showed curiosity about this questionnaire but did not have an interest in completing it. It was likely that the survey was not a high priority for them. The data collection tool clearly identified many respondents as "spam" - they opened the questionnaire for only a few seconds and then closed it immediately.

Lastly, this study did not quantify the level of pay or benefits. Individuals' attitudes toward fairness and compensation may vary depending on their pay level or benefits level in the organization. Future study could quantify different pay levels and benefits levels when studying employees' perceptions of compensation-related fairness and compensation satisfaction.

\section{Conclusions}

Pay satisfaction has been shown to be an important factor for organizational effectiveness. This study explored the relationship between organizational justice perceptions and the various dimensions of pay satisfaction. Consistent with Heneman and Judge's (2000) assertion, results showed that pay-related distributive justice perceptions were a stronger predictor of pay level satisfaction than pay-related procedural justice perceptions. Pay-related distributive justice perceptions and pay-related procedural justice perceptions significantly equally predicted pay structure satisfaction, 
pay raises satisfaction, and variable pay procedure satisfaction. Moreover, benefitsrelated distributive justice perceptions and benefits-related procedural justice perceptions significantly and equally predicted benefits level satisfaction. Benefits-related procedural justice perceptions were shown to be a stronger predictor of benefits determination satisfaction and benefits administration satisfaction than benefits-related distributive justice perceptions. These findings have significant theoretical and practical implications by contributing to the literature and directing organizations to maintain a high level of fairness in the workplace. 


\section{References}

Adams, J. S. (1965). Inequity in social exchange. In L. Berkowitz (Eds.), Advances in experimental social psychology (Vol. 2, pp. 267-299). New York: Academic Press.

Arnold, T., \& Spell, C. S. (2006). The relationship between justice and benefits satisfaction. Journal of Business and Psychology, 20, 599-620.

Chang, S. J., Van Witteloostuijn, A., \& Eden, L. (2010). From the editors: Common method variance in international business research. Journal of International Business Studies, 41, 178-184.

Cohen-Charash, Y., \& Spector, P. E. (2001). The role of justice in organizations: A metaanalysis. Organizational Behavior and Human Decision Processes, 86, 278-321.

Colquitt, J. A. (2001). On the dimensionality of organizational justice: A construct validation of a measure. Journal of applied psychology, 86, 386-400.

Currall, S. C., Towler, A. J., Judge, T. A., \& Kohn, L. (2005). Pay satisfaction and organizational outcomes. Personnel Psychology, 58, 613-640.

Davis, E., \& Ward, E. (1995). Health benefit satisfaction in the public and private sectors: The role of distributive and procedural justice. Public Personnel Management, 24, 255-270.

Day, N. E. (2011). Perceived pay communication, justice and pay satisfaction. Employee Relations, 33, 476-497.

DeConinck, J. B. (2010). The effect of organizational justice, perceived organizational support, and perceived supervisor support on marketing employees' level of trust. Journal of Business Research, 63, 1349-1355.

DeConinck, J. B., \& Stilwell, C. D. (2004). Incorporating organizational justice, role states, pay satisfaction and supervisor satisfaction in a model of turnover intentions. Journal of Business Research, 57, 225-231.

Dyer, L., \& Theriault, R. (1976). The determinants of pay satisfaction. Journal of Applied Psychology, 61, 596-604.

Faulk, L. H. (2002). Pay satisfaction consequences: Development and test of a theoretical model (Doctoral dissertation). Retrieved from Louisiana State University Electronic Thesis \& Dissertation. 
Folger, R., \& Konovsky, M. A. (1989). Effects of procedural and distributive justice on reactions to pay raise decisions. Academy of Management Journal, 32, 115-130.

Fong, S., \& Shaffer, M. (2003). The dimensionality and determinants of pay satisfaction: A cross-cultural investigation of a group incentive plan. International Journal of Human Resource Management, 14, 559-580.

Ghazanfar, F., Chuanmin, S., Khan, M. M., \& Bashir, M. (2011). A study of relationship between satisfaction with compensation and work motivation. International Journal of Business and Social Science, 2, 120-131.

Gomez-Mejia, L. R., \& Balkin, D. B. (1984). Faculty satisfaction with pay and other job dimensions under union and nonunion conditions. Academy of Management Journal, 27, 591.

Greenberg, J. (1987). A taxonomy of organizational justice theories. Academy of Management Review, 12, 9-22.

Heneman III, H. G., \& Schwab, D. P. (1985). Pay satisfaction: Its multidimensional nature and measurement. International journal of Psychology, 20, 129-141.

Heneman, H. G. III, \& Judge, T. A. (2000). Compensation attitudes. In S. L. Rynes \& B. Gerhart (Eds.) Compensation in Organizations: Current Research and Practice (pp. 61-103). San Francisco, CA: Jossey-Bass.

Jawahar, I. M., \& Stone, T. H. (2011). Fairness perceptions and satisfaction with components of pay satisfaction. Journal of Managerial Psychology, 26, 297-312.

Judge, T. A. (1993). Validity of the dimensions of the pay satisfaction questionnaire: Evidence of differential prediction. Personnel Psychology, 46, 331-335.

Judge, T. A., \& Welbourne, T. M. (1994). A confirmatory investigation of the dimensionality of the Pay Satisfaction Questionnaire. Journal of Applied Psychology, 79, 461-466.

Konovsky, M. A., Folger, R., \& Cropanzano, R. (1987). Relative effects of procedural and distributive justice on employee attitudes. Representative Research in Social Psychology, 17, 15-24.

Lawler, E. E. III. (1971). Pay and organizational effectiveness. New York: McGraw-Hill.

Lawler, E. E. III. (1981). Pay and organizational development. Reading, Mass: AddisonWesley. 
Leventhal, G. S. (1980). What should be done with equity theory? New approaches to the study of fairness in social relationships. In K. Gergen, M. Greenberg, \& R. Willis (Eds.), Social exchange: Advances in theory and research (pp. 27-55). New York: Plenum Press.

Lind E. A., \& Tyler, R. R. (1988). The social psychology of procedural justice. New York: Plenum Press.

McFarlin, D. B., \& Sweeney, P. D. (1992). Research notes. Distributive and procedural justice as predictors of satisfaction with personal and organizational outcomes. Academy of Management Journal, 35, 626-637.

Miceli M. P., \& Lane M. C. (1991). Antecedents of pay satisfaction: A review and extension. In Ferris GR, Rowland KM (Eds.), Research in personnel and human resources management (Vol. 9, pp. 235-309). Greenwich, CT: JAI Press.

Milkovich, G. T., \& Newman, J. M. (1999). Compensation, 6th ed. New York, NY: McGraw- Hill.

Podsakoff, P. M., MacKenzie, S. B., Lee, J. Y., \& Podsakoff, N. P. (2003). Common method biases in behavioral research: a critical review of the literature and recommended remedies. Journal of applied psychology, 88, 879.

Rasch, R. (2013). Perception is reality: The importance of pay fairness to employees and organizations. WorldatWork Journal, Q3, 2013.

Saad, L. (2012). U.S. Workers Least Happy With Their Work Stress and Pay. Retrieved from http://www.gallup.com/poll/158723/workers-least-happy-work-stresspay.aspx

Scarpello, V., \& Jones, F. F. (1996). Why justice matters in compensation decision making. Journal of Organizational Behavior, 17, 285-299.

Smith, P. C., Kendall, L., \& Hulin, C. L. (1969). The measurement of satisfaction in work and retirement: A strategy for the study of attitudes. Chicago: Rand McNally.

Sturman, M. C., \& Short, J. C. (2000). Lump-sum bonus satisfaction: testing the construct validity of a new pay satisfaction dimension. Personnel Psychology, 53, 673-700.

Sumod, S. J., \& Premarajan, R. K. (2011). Effects of distributive and procedural justice perceptions on managerial pay and job satisfaction. The IUP Journal of Organizational Behavior, 10, 7-25. 
Sweeney, P. D., \& McFarlin, D. B. (1993). Workers' evaluations of the" ends" and the" means": An examination of four models of distributive and procedural justice. Organizational Behavior and Human Decision Processes, 55, 23-40.

Tang, T. L. P., \& Chiu, R. K. (2003). Income, money ethic, pay satisfaction, commitment, and unethical behavior: Is the love of money the root of evil for Hong Kong employees?. Journal of Business Ethics, 46, 13-30.

Tang, T. L. P., \& Sarsfield-Baldwin, L. J. (1996, April). Distributive and procedural justice as related to satisfaction and commitment. Paper presented at the annual meeting of the Southwestern Psychological Association, Houston, TX.

Tang, T. L. P., Tang, T. L. N., \& Homaifar, B. Y. (2006). Income, the love of money, pay comparison, and pay satisfaction: Race and gender as moderators. Journal of Managerial Psychology, 21, 476-491.

Terpstra, D. E., \& Honoree, A. L. (2003). The relative importance of external, internal, individual and procedural equity to pay satisfaction: Procedural equity may be more important to employees than organizations believe. Compensation \& Benefits Review, 35, 67-74.

Tremblay, M., Sire, B., \& Balkin, D. B. (2000). The role of organizational justice in pay and employee benefit satisfaction, and its effects on work attitudes. Group \& Organization Management, 25, 269-290.

Tremblay, M., Sire, B., \& Pelchat, A. (1998). A study of the determinants and of the impact of flexibility on employee benefit satisfaction. Human Relations, 51, 667688.

Vandenberghe, C., \& Tremblay, M. (2008). The role of pay satisfaction and organizational commitment in turnover intentions: A two-sample study. Journal of Business and Psychology, 22, 275-286.

Weiner, N. (1980). Determinants and behavioral consequences of pay satisfaction: A comparison of two models. Personnel Psychology, 33, 741-757.

Weiss, D. J., Dawis, R. V., \& England, G. W. (1967). Manual for the Minnesota Satisfaction Questionnaire. Minnesota studies in vocational rehabilitation.

Welbournel, T. M., \& Cable, D. M. (1995). Group incentives and pay satisfaction: Understanding the relationship through an identity theory perspective. Human Relations, 48, 711-726. 
Williams, M. L., McDaniel, M. A., \& Nguyen, N. T. (2006). A meta-analysis of the antecedents and consequences of pay level satisfaction. Journal of Applied Psychology, 91, 392-413.

Williams, M. L., Brower, H. H., Ford, L. R., Williams, L. J., \& Carraher, S. M. (2008). A comprehensive model and measure of compensation satisfaction. Journal of Occupational and Organizational Psychology, 81, 639-668.

William M. Mercer, Inc. (1998b). 7995 Policies and Practices Survey. Louisville, KY: Author

Wu, X., \& Wang, C. (2008). The impact of organizational justice on employees' pay satisfaction, work attitudes and performance in Chinese hotels. Journal of Human Resources in Hospitality \& Tourism, 7, 181-195. 


\section{Appendix}

Survey Items

$\underline{\text { Pay-related Distributive Justice - Revised (Colquitt, 2001) }}$

1. Does the pay reflect the effort you put into work?

2. Is the pay appropriate for the work you have completed?

3. Does your pay reflect your contributions to the organization?

4. Is your pay justified given your performance?

$\underline{\text { Benefits-related Distributive Justice - Revised (Colquitt, 2001) }}$

1. Do the benefits reflect the effort you put into work?

2. Are the benefits appropriate for the work you have completed?

3. Do your benefits reflect your contributions to the organization?

4. Are your benefits justified given your performance?

$\underline{\text { Pay-related Procedural Justice - Revised (Colquitt, 2001) }}$

1. Have you been able to express your views and feelings about pay-related procedures of your organization?

2. Have you had influence over the pay you receive?

3. Are pay-related procedures applied consistently?

4. Are pay-related procedures free of bias?

5. Are pay-related procedures based on accurate information?

6. If you wanted to, could you appeal the pay you receive?

7. Are pay-related procedures based on good ethical and moral standards?

Benefits-related Procedural Justice - Revised (Colquitt, 2001)

1. Have you been able to express your views and feelings about benefits-related procedures of your organization?

2. Have you had influence over the benefits you receive?

3. Are benefits-related procedures applied consistently?

4. Are benefits-related procedures free of bias?

5. Are benefits-related procedures based on accurate information?

6. If you wanted to, could you appeal the benefits you receive?

7. Are benefits-related procedures based on good ethical and moral standards?

Pay Level Satisfaction (Williams, Brower, Ford, Williams \& Carraher, 2008)

1. Size of my current salary

2. My take home pay

3. My current salary 
4. My overall level of pay

$\underline{\text { Pay Structure Satisfaction (Williams, Brower, Ford, Williams \& Carraher, 2008) }}$

1. The pay differences between jobs at different organizational levels

2. Pay of other jobs in the organization

3. Differences in pay among jobs in the organization

4. The pay differences between my job and jobs one level above mine in the pay hierarchy

5. The pay differences between my job and jobs one level below mine in the pay hierarchy

$\underline{\text { Pay Raises Satisfaction (Williams, Brower, Ford, Williams \& Carraher, 2008) }}$

1. The size of recent pay increases

2. The size of my most recent raise

3. The size of raises I have typically received in the past

4. How my raises are determined

Variable Pay Procedure Satisfaction (Williams, Brower, Ford, Williams \& Carraher, $\underline{2008)}$

1. How my bonuses are determined

2. The way bonuses, incentives, and commissions are used in this organization

3. The procedures and criteria used in determining forms of pay such as bonuses, incentives, and commissions

Benefits Level Satisfaction (Williams, Brower, Ford, Williams \& Carraher, 2008)

1. My benefit package

2. Amount the organization pays toward my benefits

3. The value of my benefits

4. The number of benefits I receive

Benefits Determination Satisfaction (Williams, Brower, Ford, Williams \& Carraher, 2008)

1. The say I have in the benefits I receive

2. Employee involvement in benefit planning

3. The choice employees have in the benefits they receive

Benefits Administration Satisfaction (Williams, Brower, Ford, Williams \& Carraher, 2008)

1. How the benefits program is administered

2. The effectiveness of the system that provides my benefits 
3. The arrangements my organization has made for the delivery of my benefits

4. The efficiency with which benefits are provided

5. What I am told about my benefits

6. The information I receive about my benefits

\section{Demographics}

1. What is your age?

2. What gender do you identify with?

o Male

o Female

3. What ethnicity do you most identify with?

o White

o Hispanic

o African American/Black

o Native American

o Asian/Pacific Islander

o Two or more ethnicity

o Other

4. What is the highest level of education obtained?

o Less than a high school diploma

o High School diploma

o Vocational/Trade school diploma

o Associate's Degree

o Bachelor's Degree o Master's Degree

o Doctorate Degree

o Other

5. What is your employment status?

o Part-time employee

o Full-time employee

o Contract/Temp worker

6. What is your job type?

o Accountancy, banking and finance

o Business, consulting, and management

o Creative arts and design

o Education

o Engineering and manufacturing

o Healthcare

o Hospitality

o Human resources

o Information technology

o Law 
o Media and internet

o Public services and administration

o Retail

o Sales

o Social care

o Transport and logistics

o Other

7. Is your salary based on commission?

o Yes

o No

8. Is the organization you are working for?

o Unionized

o Not unionized

9. The size of the organization you are working for is

o 1-50 employees

o 51-200 employees

o 201-500 employees

o 501-1000 employees

o 1001-5000 employees

o 5001-10,000 employees

o 10,001+ employees 